\title{
New Myloplus from Essequibo River basin, Guyana, with discussion on the taxonomic status of Myleus pacu (Characiformes: Serrasalmidae)
}

\author{
Marcelo C. Andrade ${ }^{1}$, Hernán López-Fernández ${ }^{2,3}$ and Elford A. Liverpool ${ }^{4}$
}

A new species in the serrasalmid genus Myloplus is described from the middle Mazaruni River, Essequibo River basin, Guyana. The new species is similar to Myleus pacu and Myloplus planquettei in its silver to purplish black coloration and its overall morphology, and has a putative syntopic distribution with those species. The new species is, however, readily distinguishable from the other two by meristic counts of the unpaired fins and by differences in color pattern, primarily in males. Additionally, we provide comments on Myleus pacu and other species that have been confounded under that name.

Keywords. Endemic, Myletes, Sexually dichromatism, Species inquirenda, Taxonomy.

Uma nova espécie de serrasalmídeo do gênero Myloplus é descrita do médio rio Mazaruni, bacia do rio Essequibo, Guyana. A nova espécie é similar a Myleus pacu e Myloplus planquettei pela sua coloração prateada a preto arroxeado e pela morfologia geral do corpo, e por ter suposta distribuição sintópica com essas espécies. No entanto, a nova espécie é prontamente distinguida dessas duas últimas espécies por contagens das nadadeiras não pares, e por diferenças no padrão de coloração, principalmente nos machos. Adicionalmente, fornecemos comentários sobre Myleus pacu e outras espécies que têm sido confundidas sob esse nome.

Palavras-chave. Dicromatismo sexual, Endêmico, Myletes, Species inquirenda, Taxonomia.

\section{Introduction}

The diversity of the Serrasalmidae "pacu" genus Myloplus Gill, 1896, with 14 currently recognized species, is second only to the most speciose herbivores of the genus Metynnis Cope, 1878, which contains 15 named species (Ota et al., 2016; Fricke et al., 2019). Myloplus has a broad distribution throughout South America with its greatest diversity in the Amazon basin (Nico et al., 2018). Myloplus diversity remains incompletely characterized and has increased modestly in recent years (Andrade et al., 2016a,b, 2018a). Outside the Amazon basin, Myloplus is particularly diverse in the coastal drainages of the Guiana Shield, encompassing the Orinoco, Essequibo, and Atlantic flowing river basins of the Guianas, which harbor ten recognized species (Fricke et al., 2019): Myloplus asterias (Müller, Troschel, 1844), Myloplus arnoldi Ahl, 1936, Myloplus lobatus (Valenciennes, 1850), Myloplus planquettei Jégu, Keith, Le Bail, 2003, Myloplus rhomboidalis (Cuvier, 1818), Myloplus rubripinnis (Müller, Troschel, 1844), Myloplus schomburgkii (Jardine, 1841),
Myloplus ternetzi (Norman, 1929), Myloplus torquatus (Kner, 1858), and Myloplus tumukumak Andrade, Jégu, Gama, 2018. Despite this diversity and of relatively detailed historical sampling of their ichthyological diversity (e.g., Eigenmann, 1912; Géry, 1972), tributaries of the Guiana Shield continue to reveal previously undescribed species of Myloplus.

In this paper, we report and describe a previously unknown species of Myloplus from the Mazaruni River, a tributary of the Essequibo River basin in Guyana. This species was initially identified as Myleus pacu (Jardine, 1841) because of its silver to purplish black coloration and its supposedly syntopic distribution with that species. However, this previously unknown species has molariform teeth and premaxillary rows separated by a clear gap characteristic of the genus Myloplus, whereas Myleus is characterized by two adjacent rows of incisiform teeth in contact with each other (Andrade et al., 2018b). Additionally, we provide some comments on characters distinguishing Myleus pacu and other species that have been confounded under that name.

\footnotetext{
${ }^{1}$ Núcleo de Ecologia Aquática e Pesca da Amazônia, Universidade Federal do Pará, Av. Perimetral 2651, 66040-830 Belém, PA, Brazil. andrademarcosta@gmail.com, Dhttps://orcid.org/0000-0002-3573-5774 (corresponding author).

${ }^{2}$ Department of Natural History, Royal Ontario Museum, 100 Queen's Park, Toronto, ON M5S 2C6, Canada.

${ }^{3}$ Current address: Department of Ecology and Evolutionary Biology and Museum of Zoology, University of Michigan, 1105 North University Ave. Ann Arbor, MI 48109 United States of America. hlopezf@umich.edu, Ohttps://orcid.org/0000-0003-0270-1671.

${ }^{4}$ Department of Biology, Faculty of Natural Sciences, University of Guyana, Turkeyen Campus, Georgetown, Guyana. elford.liverpool@ uog.edu.gy, Dhttps://orcid.org/0000-0003-1300-8821.
} 


\section{Material and Methods}

Measurements and counts follow Jégu et al. (2003) with addition of caudal-peduncle length. Standard length (SL) is expressed in millimeters and all other measurements are expressed as percentage of SL, except for subunits of head, which are expressed as percentage of head length (HL). Counts are given in the description followed by frequency of each count in parentheses; counts observed in the holotype are indicated by an asterisk. Osteological terminology follows Weitzman (1962) with modifications based on Mattox et al. (2014). Osteological descriptions, vertebral and supraneural counts were based on radiographed specimens. Vertebrae of the Weberian apparatus are counted as four elements and the compound caudal centra (PU1+U1) as one element.

Institutional abbreviations are as follows: BMNH (Natural History Museum, London), CSBD (Ichthyology Collection of the Centre for the Study of Biological Diversity, University of Guyana, Georgetown), GEA (Laboratório de Ictiologia do Grupo de Ecologia Aquática, UFPA, Belém), INPA (Instituto Nacional de Pesquisas da Amazônia, Manaus), MNHN (Muséum National d'Histoire Naturelle, Paris), NMW (Naturhistorisches Museum Wien, Vienna), ROM (Royal Ontario Museum, Toronto), TAMU (Texas A\&M University, College Station), UFGD (Universidade Federal da Grande Dourados, Dourados), UFPA (Universidade Federal do Pará, Belém), UMMZ (University of Michigan Museum of Zoology, Ann Arbor), ZMA (Zoologisch Museum Universiteit van Amsterdam; specimens now at RMNH - Rijksmuseum Museum van Natuurlijke Historie, Leiden), and ZMB (Museum für Naturkunde Berlin, Berlin).

\section{Results}

\section{Myloplus taphorni, new species}

urn:1sid:zoobank.org:act:E864BAA6-2D13-4E11-B5769CA0A5DB5EF2

Holotype. CSBD F 3611, $143.3 \mathrm{~mm}$ SL, Guyana, Mazaruni River at mouth of Kurupung River, $6^{\circ} 12.846^{\prime} \mathrm{N}$ $60^{\circ} 09.394^{\prime} \mathrm{W}, 21$ March 2016, E. Liverpool, D.C. Taphorn, H. López-Fernández, M. Ram, K. Dookram, D. Hemraj, J. Correia.

Paratypes. ROM 101261, 1, $145.7 \mathrm{~mm} \mathrm{SL}$, same data of holotype; ROM 101262, 1, 142.4 mm SL, Guyana, Lower Kurupung River, 22 March 2016, E. Liverpool, D.C. Taphorn, H. López-Fernández, M. Ram, K. Dookram, D. Hemraj, J. Correia; UMMZ 251911, 1, 154.9 mm SL, Guyana, Eping Creek, tributary of the Mazaruni River, $6^{\circ} 08.151^{\prime} \mathrm{N} 60^{\circ} 04.470$ 'W, 20 March 2016, E. Liverpool, D.C. Taphorn, H. López-Fernández, M. Ram, K. Dookram, D. Hemraj, J. Correia.
Diagnosis. Myloplus taphorni differs from all congeners, except M. asterias, M. levis (Eigenmann, McAtee, 1907), M. rubripinnis, and M. tumukumak, by combination of a higher number of branched rays in both dorsal and anal fin (23-25 and 33-34, branched dorsal-fin and anal-fin rays, respectively, vs. 20-21 and 27-29 in M. arnoldi, 21-22 and 32-34 in M. lobatus, 18-22 and 31-34 in M. lucienae Andrade, Ota, Bastos, Jégu, 2016, 18-21 and 32-34 in $M$. planquettei, 21-22 and 30-33 in M. rhomboidalis, 20-21 and 30-36 in M. schomburgkii, 22-25 and 28-29 in $M$. ternetzi, 24-25 and 30-33 in M. tiete (Eigenmann, Norris, 1900), 23-24 and 29-30 in M. torquatus, 20-22 and 3234 in M. zorroi Andrade, Jégu, Giarrizzo, 2016). Myloplus taphorni differs from $M$. asterias by having a shorter caudal-peduncle length $(8.8-9.7 \%$ SL vs. $10.2-12.0 \%$ $\mathrm{SL}$ ), and further by possessing anterior and posterior fontanels elongated and about the same size vs. anterior fontanel large, wide and rounded and posterior fontanel minute, narrow and triangle shaped. Myloplus taphorni differs from $M$. levis by having a reddish gray (male) or completely hyaline (female) anal fin $v s$. anal fin with an evident black mark present on the anterodistal portion in both sexes. Myloplus taphorni is distinguished from M. tumukumak, and additionally from $M$. lucienae, $M$. planquettei, and M. zorroi by having more series of scales between the lateral line and the pelvic-fin origin (37-39 vs. 24-29 in M. tumukumak, 27-31 in M. lucienae, 32-40 in M. planquettei, and 36-42 in M. zorroi). Additionally, M. taphorni differs from $M$. arnoldi, M. asterias, $M$. lobatus, M. lucienae, M. rhomboidalis, M. rubripinnis, and $M$. torquatus by having a shorter postorbital distance (24.4-25.7\% HL vs. $27.8-32.0 \%$ HL in M. arnoldi, 27.9 $34.2 \% \mathrm{HL}$ in $M$. asterias, $26.9-32.3 \% \mathrm{HL}$ in M. lobatus, $30.4-36.8 \% \mathrm{HL}$ in $M$. lucienae, $26.9-32.0 \% \mathrm{HL}$ in $M$. rhomboidalis, 26.2-32.6\% HL in M. rubripinnis, and $38.1-38.8 \% \mathrm{HL}$ in M. torquatus).

Description. Morphometric data in Tab. 1. Body deep, rounded to slightly elongated (and see Sexual dimorphism), highest body depth at dorsal-fin origin (Figs. 1a-c). Blunt snout. Big eye. Dorsal profile of head gently concave, predorsal profile and dorsal-fin base slightly convex. Dorsal profile between dorsal-fin base terminus and adipose-fin origin short and straight. Ventral profile of head and body convex. Anal-fin base straight to pronouncedly convex. Caudal peduncle with dorsal and ventral profiles convex.

Upper and lower jaws equal, mouth terminal. Rows of premaxillary teeth separated by an edentulous gap. Five*(4) molariform teeth in outer premaxillary row and $2 *(4)$ in inner row. Dentary with $5 *(4)$ molariform teeth, and pair*(4) of teeth at dentary symphysis. Symphyseal tooth with cutting edge in anterior portion. Maxilla edentulous. First gill arch with 14(1) gill rakers on upper branch, 15(1) rakers on lower branch, and 1(1) raker on intermediate cartilage. 
Tab. 1. Morphometric data of Myloplus taphorni from Essequibo River basin, Guyana. SD=Standard Deviation.

\begin{tabular}{|c|c|c|c|c|c|c|}
\hline & \multirow{2}{*}{$\begin{array}{c}\text { Holotype } \\
\text { CSBD F } 3611\end{array}$} & \multicolumn{3}{|c|}{ Paratypes } & \multirow[t]{2}{*}{ Mean } & \multirow[t]{2}{*}{ SD } \\
\hline & & ROM 101261 & ROM 101262 & UMMZ 251911 & & \\
\hline Standard length (mm) & 143.3 & 145.7 & 142.4 & 154.9 & & \\
\hline \multicolumn{7}{|c|}{ Percentages of SL } \\
\hline Body depth & 72.7 & 72.8 & 78.9 & 69.1 & 73.4 & 4.1 \\
\hline Head length & 26.1 & 25.4 & 25.8 & 25.5 & 25.7 & 0.3 \\
\hline Distance from snout to supraoccipital spine & 33.0 & 34.5 & 33.8 & 34.2 & 33.9 & 0.7 \\
\hline Predorsal length & 58.3 & 59.0 & 60.9 & 58.5 & 59.2 & 1.2 \\
\hline Dorsal-fin base length & 36.5 & 34.6 & 36.3 & 36.2 & 35.9 & 0.9 \\
\hline Interdorsal length & 9.1 & 10.1 & 9.0 & 9.2 & 9.4 & 0.5 \\
\hline Adipose-fin base length & 4.6 & 3.7 & 4.7 & 4.2 & 4.3 & 0.5 \\
\hline Caudal-peduncle length & 9.7 & 9.2 & 8.9 & 8.8 & 9.2 & 0.4 \\
\hline Caudal-peduncle depth & 10.5 & 10.0 & 9.9 & 9.3 & 9.9 & 0.5 \\
\hline Caudal peduncle width & 3.3 & 3.4 & 3.9 & 3.6 & 3.6 & 0.3 \\
\hline Prepectoral length & 29.7 & 28.4 & 27.9 & 28.1 & 28.5 & 0.8 \\
\hline Pectoral-fin length & 21.7 & 19.9 & 21.3 & 20.3 & 20.8 & 0.8 \\
\hline Pelvic-fin origin to anal-fin origin & 20.4 & 22.8 & 21.2 & 21.8 & 21.6 & 1.0 \\
\hline Pectoral-fin origin to pelvic-fin origin & 31.6 & 32.7 & 37.6 & 32.6 & 33.6 & 2.7 \\
\hline Prepelvic length & 60.6 & 60.8 & 65.3 & 60.2 & 61.7 & 2.4 \\
\hline Pelvic-fin length & 14.7 & 14.0 & 14.1 & 14.1 & 14.2 & 0.3 \\
\hline Preanal length & 79.0 & 80.2 & 75.0 & 79.3 & 78.4 & 2.3 \\
\hline Anal-fin base length & 40.4 & 38.2 & 41.4 & 37.7 & 39.4 & 1.8 \\
\hline First anal-fin lobe length & 20.8 & - & 24.1 & 17.7 & 20.9 & 3.2 \\
\hline Second anal-fin lobe length & 14.3 & - & - & 16.2 & 15.3 & 1.3 \\
\hline Dorsal-fin lobe length & 27.1 & 25.9 & 28.4 & 25.3 & 26.7 & 1.4 \\
\hline Dorsal-fin origin to anal-fin origin & 75.2 & 74.4 & 79.5 & 72.0 & 75.3 & 3.1 \\
\hline Dorsal-fin end to anal-fin origin & 55.7 & 54.0 & 58.8 & 51.6 & 55.0 & 3.0 \\
\hline Dorsal-fin end to anal-fin end & 22.2 & 21.4 & 21.7 & 20.5 & 21.5 & 0.7 \\
\hline \multicolumn{7}{|c|}{ Percentages of $H L$} \\
\hline Snout length & 27.9 & 28.6 & 28.3 & 28.9 & 28.4 & 0.4 \\
\hline Mouth length & 16.9 & 16.9 & 14.7 & 17.3 & 16.5 & 1.2 \\
\hline Mouth width & 37.3 & 35.2 & 36.7 & 34.9 & 36.0 & 1.2 \\
\hline Interorbital width & 55.7 & 59.0 & 56.9 & 53.3 & 56.2 & 2.4 \\
\hline Head width & 64.8 & 66.0 & 67.5 & 64.7 & 65.8 & 1.3 \\
\hline Third infraorbital width & 12.5 & 13.1 & 12.4 & 11.8 & 12.5 & 0.5 \\
\hline Cheek gap width & 8.7 & 9.0 & 10.0 & 10.0 & 9.4 & 0.7 \\
\hline Fourth infraorbital width & 9.5 & 10.8 & 10.6 & 9.3 & 10.1 & 0.8 \\
\hline Eye vertical diameter & 47.3 & 46.6 & 46.7 & 45.6 & 46.6 & 0.7 \\
\hline Postorbital distance & 25.7 & 25.1 & 24.4 & 24.6 & 25.0 & 0.6 \\
\hline
\end{tabular}


Scales cycloid. Perforated lateral line scales from supracleithrum to edge of hypural plate $63(2)$ or $65^{*}(2)$; total perforated scales on lateral line from supracleithrum to base of median caudal-fin rays $67(1), 68(1), 69 *(1)$ or $70(1)$. Longitudinal scale rows between line and dorsalfin origin $36(3)$ or $37 *(1)$; longitudinal scale rows between lateral line and pelvic-fin origin $37(1), 38(1)$ or $39 *(2)$. Circumpeduncular scale rows $32 *(3)$ or $33(1)$.

Forward directed spine anterior to dorsal fin. Dorsal-fin base relatively long compared to the short space between dorsal-fin base terminus and adipose-fin origin. Dorsal-fin rays $\mathrm{ii*}(3)$ or iii(1), and $23^{*}(2), 24(1)$ or $25(1)$. Anal-fin rays iii*(4), and $33^{*}(2)$ or $34(2)$. Pectoral-fin rays i*(4), and $12(1), 14(1)$ or $15^{*}(2)$. Pelvic-fin rays $i, 6^{*}(4)$. Adipose fin tear drop shaped. Caudal fin forked, dorsal and ventral lobes approximately equal in size.

Ventral keel scutes prominent, with large spines. Anterior most spine reaching or surpassing vertical through pectoralfin origin (Fig. 2). Prepelvic serra with 21(1), 22*(1), 23(1) or 25(1) spines. Postpelvic serra with $5(1), 6^{*}(2)$ or $7(1)$ simple spines, and $5^{*}(2)$ or $6(2)$ pairs of spines around anus. Total serra with 32(1) $33 *(1)$ or 36(2) spines.

Neurocranium triangular, as long as high (Fig. 2). Fontanels elongated and equal sized. Ascending premaxilla process elongated, massive, and well fused to neurocranium. Dentary short with ventral edge straight. First dorsal-fin pterygiophore inserted between neural spines of vertebrae 10th and 11th(1), or between 9th and 10th(1), 5(1) or 6(1) supraneurals. Nine (1) or 10(1) predorsal vertebrae, 5(2) vertebrae between first anal-fin pterygiophore and last dorsal-fin pterygiophore, 12(2) vertebrae posterior to last dorsal-fin pterygiophore. First dorsal-fin pterygiophore posterior to neural spine of 9th(1) or 10th(1) centrum. First anal-fin pterygiophore posterior to haemal spine of 22nd(2) centrum. Thirty-seven(1) to 38(1) total vertebrae, 21(2) precaudal and 17(1) or 18(1) caudal vertebra (Fig. 2).

Coloration in alcohol. Background coloration yellowish silver (Figs. 1a-c). Flank homogeneously yellowish silver, countershaded (females, Fig. 1c) or with black coloration pattern (males, and see coloration under Sexual dimorphism for details), mainly concentrated on dorsal half of flank (Figs. 1a-b). Eye with well-marked vertical black bar, anterior and posterior portions of sclerotic clear to light yellow. Infraorbital series lacking pigmentation or with very few dark chromatophores on 1st, 2nd and/or 3 rd infraorbitals. Opercle silver, anteromedial portion with very few dark chromatophores. Belly silver or light brown. Fins hyaline to light brown with few chromatophores scattered on rays and hyaline membrane between rays. Dorsal fin generally light brown with discrete black pigmentation distally on anterior rays. Adipose light brown to clear or with a very thin brown edge. Anal rays with dark chromatophores along base and extending to middle portion of rays or uniformly light brown. Caudal fin yellow to light brown, distally whitish gray.
Coloration in life. Background coloration silver to purplish silver, especially in males (Fig. 3a); females silver to bluish silver (Fig. 3b). Dorsal portion of head brownish black, ventrally and posterior to eye light silver. Upper portion of 3rd and 4th infraorbital and operculum light olive green. Eye with conspicuous vertical black bar, anterior and posterior portions of sclerotic bright yellow. Flank homogeneous silvery or with evident scattered pattern of black scales, mainly on upper flank. Belly silver or light black and metallic purple. Pectoral, pelvic and adipose hyaline to light yellow. Dorsal, anal and caudal fins yellow-orange to bright or brownish red.

Sexual dimorphism. Males and females are distinguished mainly by differences in coloration. Background coloration of dorsal region of males distinctly brownish red (Figs. 1a-b, 3), ventrally purple to purplish silver with a dark purple, almost black, diffuse band on the ventral-most quarter of the flank. Females are primarily silver with a distinct bluish veneer in life (Figs. 1c, 3). Male flank with a whitish silver medial region above and below the lateral line, bordered by deep black scales, most of which are overlaid with a metallic green sheen; perforated scales and lateral line pigmented black at center. Males also recognized by the presence of elongated middle anal fin rays, forming a lobe with apex centered on 16th branched ray. Females with first anal fin ray clear, longest, decreasing in size towards posterior portion of fin. Males lack stiff hooks on distalmost lepidotrichia of anal-fin rays and filamentous extensions on dorsal-fin rays.

Geographical distribution. Myloplus taphorni is currently known only from two tributaries of the middle reaches of the Mazaruni River, Essequibo River basin, Guyana (Fig. 4).

Ecological notes. The species was collected in black water channels (Fig. 5) between 25 and $75 \mathrm{~m}$ wide. Water characteristics at the two sites were similar, with temperature between $26.7-29{ }^{\circ} \mathrm{C}, \mathrm{pH}$ of 5.1 , extremely low conductivity between $4-12 \mu \mathrm{S} / \mathrm{m}$ and secchi depth between $65-85 \mathrm{~cm}$. Both sites had bottom consisting of a mixture of sand and coarse gravel, likely a semi-natural substrate transformed at least partially by ongoing or past gold mining activities in the area (see Discussion). Specimens were collected near large rocks or submerged woody debris at depths of $1 \mathrm{~m}$ or deeper.

Etymology. The species is named in honor of American ichthyologist Dr. Donald C. Taphorn in recognition of over four decades of continuing contributions to Neotropical ichthyology, his expansive role in training South American ichthyologists (including the authors), and for his participation in the expedition to the middle Mazaruni during which the new Myloplus was collected. 

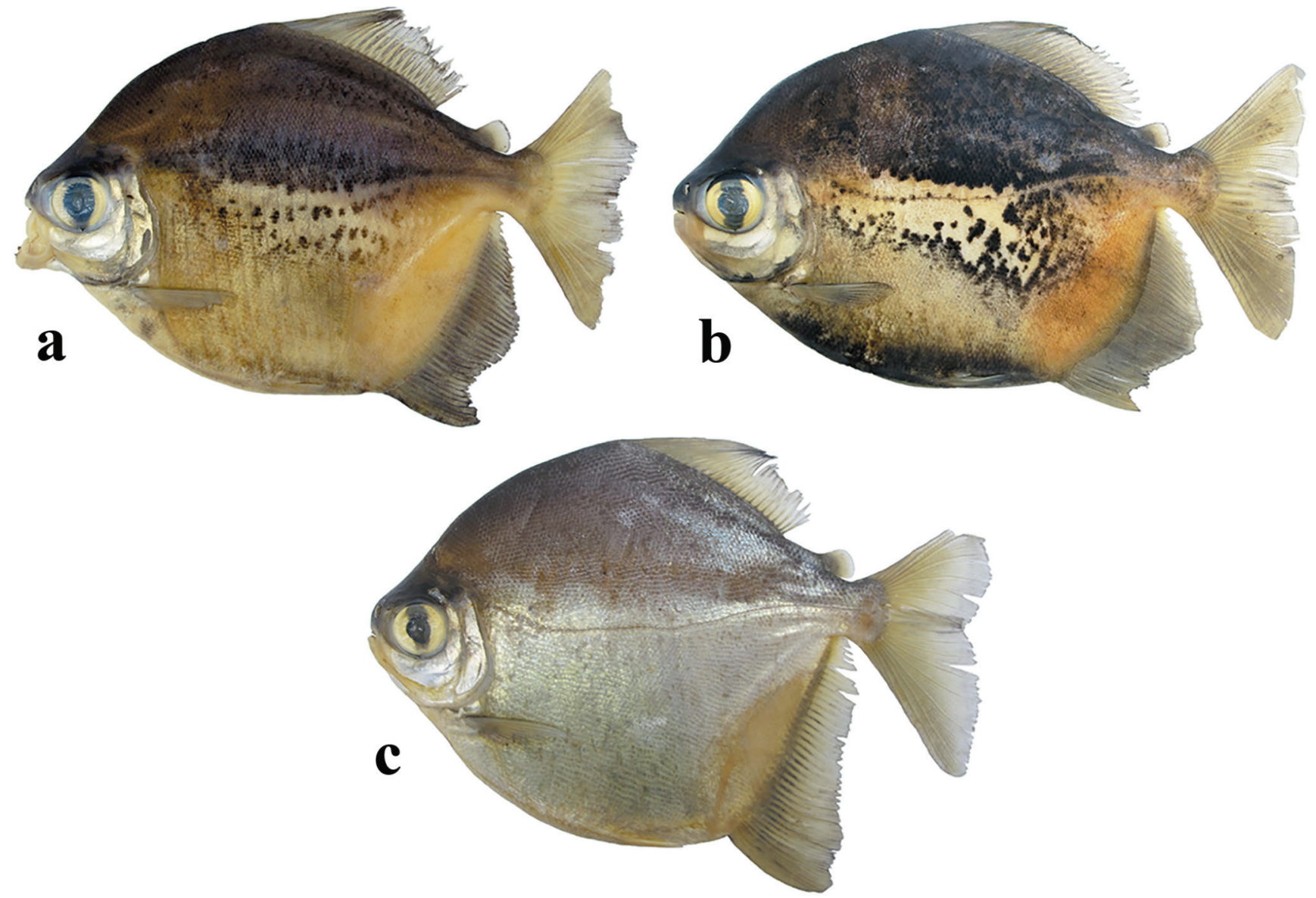

Fig. 1. Myloplus taphorni: Guyana, Essequibo Basin. a. Holotype, CSBD F 3611, male, 143.3 mm SL; Paratypes, b. UMMZ 251911, male, $154.9 \mathrm{~mm}$ SL, and c. ROM 101262, female, $142.4 \mathrm{~mm}$ SL. Photos: MCA.

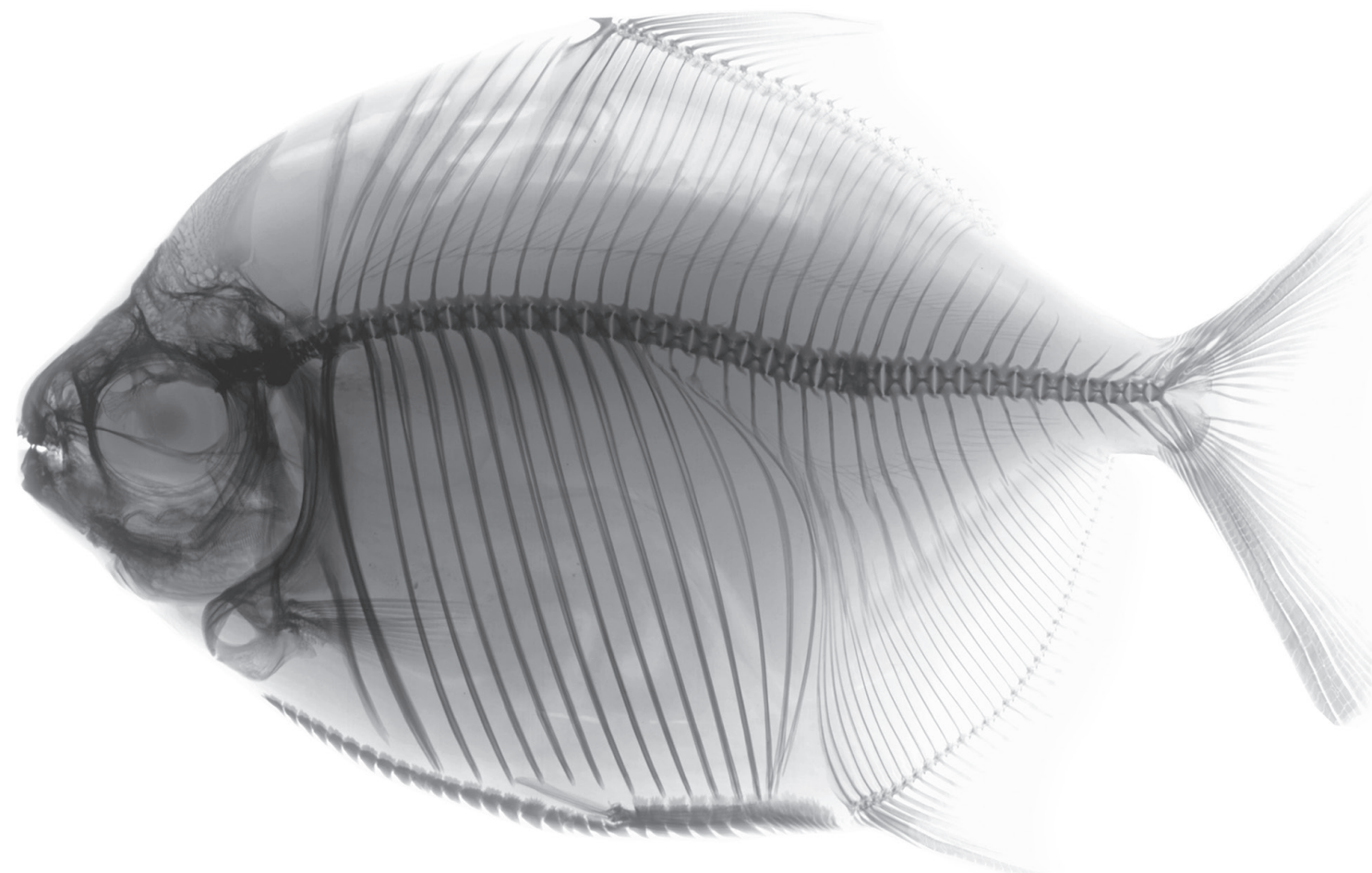

Fig. 2. Radiograph of Myloplus taphorni, paratype, UMMZ 251911, male, 154.9 mm SL. Courtesy E. Holm (ROM). 

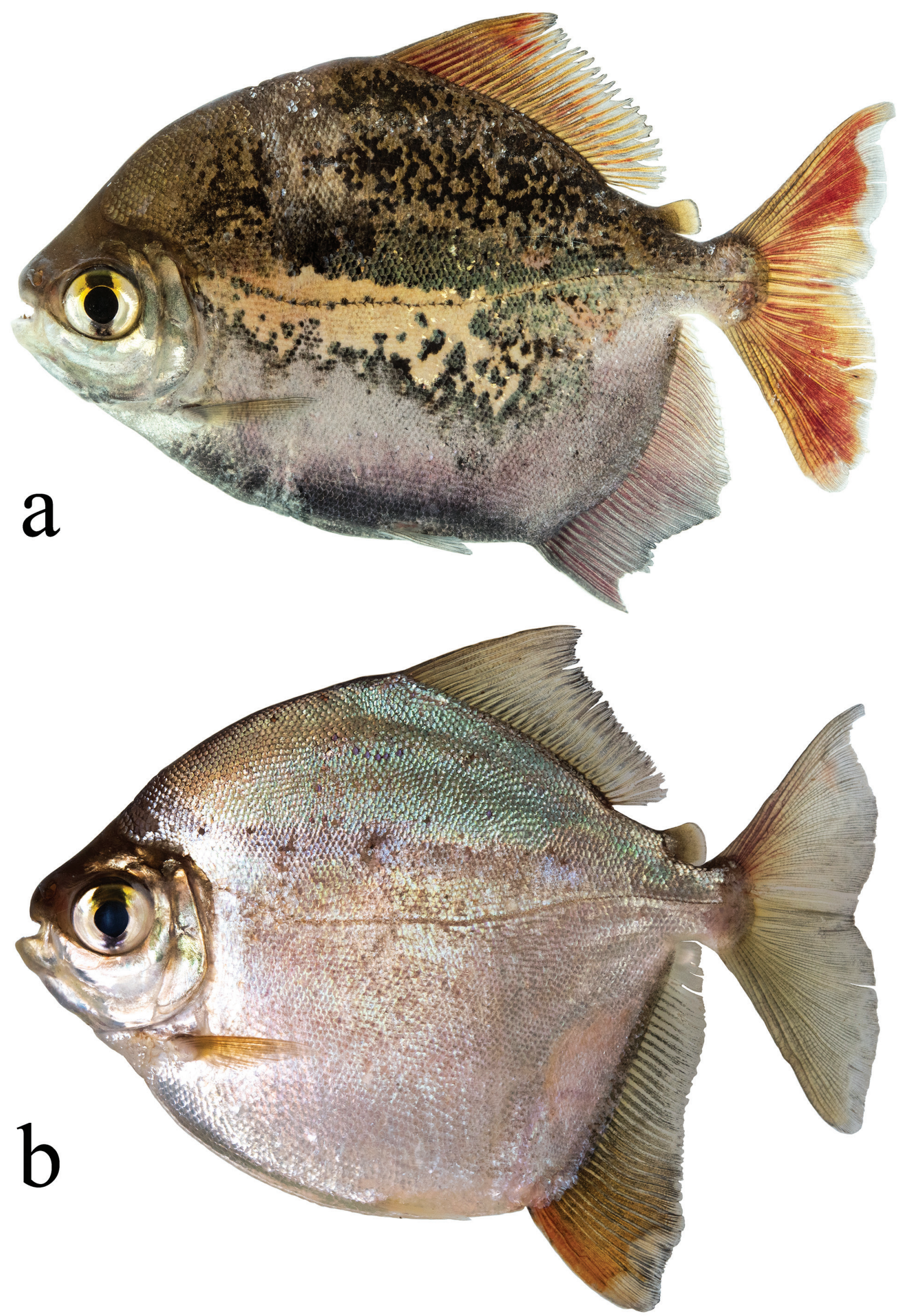

Fig. 3. Myloplus taphorni photographed shortly after capture. a. Male, paratype, UMMZ 251911, male, $154.9 \mathrm{~mm}$ SL, Guyana, Eping creek. b. Female, paratype, ROM 101262, 142.4 mm SL, Guyana, Lower Kurupung River. Photos: HLF. 


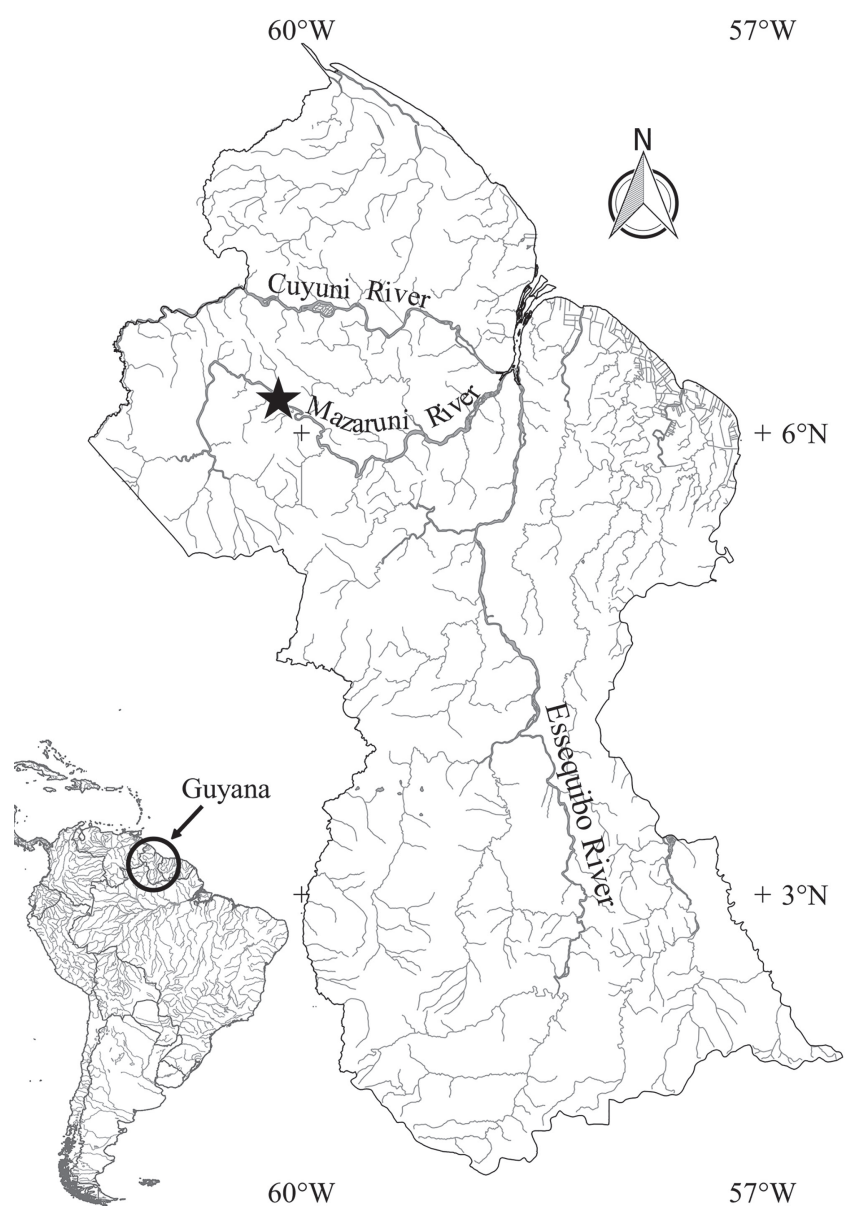

Fig. 4. Distribution map of Myloplus taphorni in middle Mazaruni River indicated by the black star.

\section{Discussion}

Herbivorous serrasalmids are known to show dimorphic traits; specifically, males are often distinguished by presenting red patches scattered over the flanks, having a dorsal fin with elongated filaments, the branched rays of the anal fin prolonged forming an apex on the middle of the fin, and frequently the presence of stiff hooks on the distalmost anal lepidotrichia (Andrade et al., 2016c; Pastana et al., 2017). Males and females of Myloplus taphorni are readily distinguished by the coloration of the males, which consist of striking purplish silver flanks with conspicuous black overtones composed by scales intensely pigmented and often with a metallic green sheen, whereas females are mainly bluish silver without any evident pigmentation or markings (Fig. 3). The presence of evident marks on males of Myloplus taphorni is reminiscent of the congeners $M$. asterias and M. planquettei, however, the coloration pattern exhibited by males $M$. taphorni is unique in having many scales fully pigmented in black forming a vermiculated pattern around a distinct silvery or yellowish region that may present black spotting on and below the lateral line (Fig. 2). In turn, males of $M$. asterias and $M$. planquettei show some black aureoles

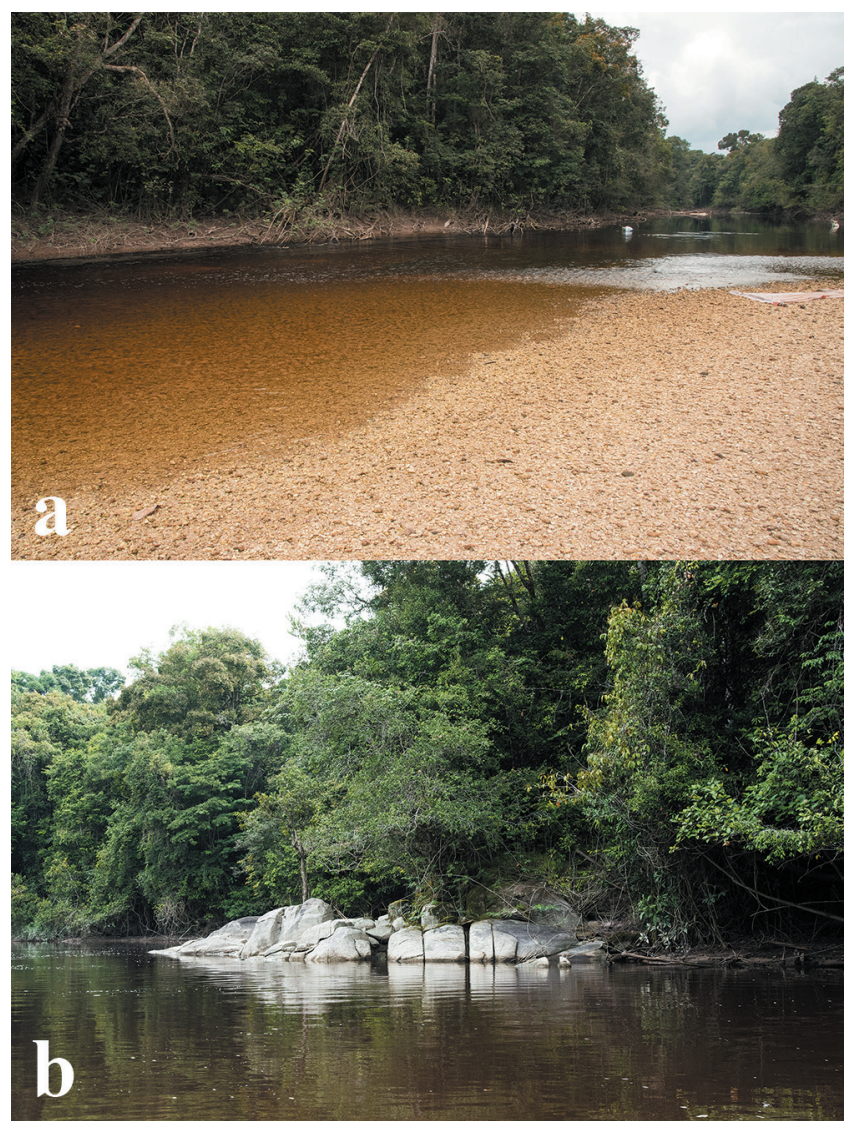

Fig. 5. Collection localities for Myloplus taphorni. a. Eping Creek; b. Type locality, Lower Kurupung River near the mouth. Both streams are tributaries of the middle Mazaruni River, Guyana. Photos: HLF.

or near ocellated spotting with reddish yellow inside or amorphous patches fully blackened and covering most of the flanks. Even though M. taphorni shares a general coloration pattern with M. asterias and M. planquettei and all three species are putatively syntopic, the new species is readily distinguishable on the basis of its coloration, particularly among males, and by meristic counts of the unpaired fins and/or relative length of body subunits. Additionally, Myloplus taphorni of both sexes display a conspicuous vertical black band through the eye, which contrasts sharply with a light yellowish sclerotic on the anterior and posterior portions of the eye. In M. asterias and $M$. planquettei the sclera is homogeneously pigmented and invariably without a vertical stripe. The vertical band crossing the eye is registered in literature in carnivorous piranhas such as species in the genera Pygocentrus Müller, Troschel, 1844 and Serrasalmus Lacepède, 1803 (Géry, 1977), and in Metynnis and Catoprion Müller \& Troschel, 1844 (Rafaela P. Ota, 2019, pers. comm.). The coloration of Myloplus taphorni probably led to its initial identification as the possibly syntopic Myleus pacu. However, coloration in Myleus pacu consists of a solid terracotta red background, with males showing brownish black patches scattered on the flanks. 
Jardine (1841) described Myletes pacu from drawings by Robert H. Schomburgk, who illustrated a pair of specimens from somewhere in the Essequibo River basin, both predominantly red colored with the male presenting some black patches. Jardine (1841) reported the sizes for these two Myletes pacu, the male reaching $400 \mathrm{~mm}$ and the female about $600 \mathrm{~mm}$ in total length, and the presence of 43 total rays in the anal fin for both fish. Eigenmann (1912) redescribed the genus Myleus - following the observations of Jardine (1841) on the Schomburgk's drawings-, then suggested Myletes pacu, Myleus setiger Müller, Troschel, 1844 and Tometes trilobatus Valenciennes, 1850 as synonyms of Myleus pacu, and diagnosed it as species having a marked ventral keel as juveniles and becoming less evident with growth.

Jégu, Santos (2002) revisited the taxonomic status of Myleus based on analyses of type-specimens and examined additional material and illustrations, and considered Myleus setiger as a different species from Myleus pacu. However, Jégu, Santos (2002) did not examine any specimen as large in length as those reported by Jardine (1841) at about $600 \mathrm{~mm}$ for Myletes pacu, with the maximum size reached by Myleus setiger at about $300 \mathrm{~mm}$ SL. Jégu, Santos (2002) redescribed Myleus setiger, and further mentioned that the body of Myletes pacu in Schomburgk's illustrations is very elongated and that number of rays in the anal fin described by the author is too high for any serrasalmid (43vs. overall maximum of 38 in specimens of Myleus setiger, for example). Therefore, Myleus setiger which was in synonymy of Myleus pacu since Eigenmann (1912) was revalidated by Jégu, Santos (2002). In turn, Jégu et al. (2003) considered Myleus pacu as a doubtful species due to the absence of type specimens to support its validity, and the name was listed as species inquirenda in the Check list of the freshwater fishes of South and Central America 'CLOFFSCA' (Jégu, 2003).

Myloplus taphorni appears to be an endemic species with a distribution likely limited to the middle reaches of the Mazaruni river basin in Guyana. Examination of a large amount of collections of Myloplus in natural history collections with large holdings from Guyana (ROM, ANSP, UMMZ) failed to reveal any specimens beyond the ones included in this paper. The Mazaruni River basin harbors a large proportion of endemic taxa, particularly in its upper section (Alofs et al., 2014). The middle reaches of the river are less explored: previously unidentified species of Cichlidae and Crenuchidae were also encountered in association with the Myloplus species described herein, and are in the process of being named (HLF, EAL et al., unpublished data). Unfortunately, the long-term conservation of this fish diversity is far from guaranteed. Nearly the entirety of the Mazaruni basin is extensively mined for gold using placer techniques that move and relocate vast amounts of river channel substrate or riparian soil. Our field observations revealed large-scale reconfiguration of the river consisting of homogenization of the substrate in main channels, a proliferation of "tailings beaches" artificially created by relocation of river substrate, and high turbidity caused by siltation from mining operations.
While most of this large-scale habitat remodeling is centered in the channel of the Mazaruni, tributaries such as the type locality area in the Kurupung River are also affected. Eping Creek, the only other locality where the new species was collected appears to not be mined at this time, but remains of mining equipment and clear reconfiguration of the banks and main channel indicate that mining must have been extensive in the past. More positively, it appears that Eping creek has, to an extent, recovered from some of the mining-related impacts on habitat, particularly in the reduction of suspended solids in the water column. Nevertheless, it is clear that even after mining stopped, the structure of the substrate remained an artificial mixture of sand and "tailings" (evenly sized pebbles and gravel resulting from the mining process) and that a majorly reconfigured channel structure remains in place.

Comparative material examined. Myloplus arnoldi: Brazil: MNHN 1998-1162, 2, 147.6-154.5 mm SL, Rio Xingu; ZMB 20812, 1 syntype, 43.9 mm SL, Rio Amazonas, Brazil. Myloplus asterias: Guyana: BMNH 1971.5.10:61-62, 2, 115.3-122.8 mm SL, paralectotypes of Myletes asterias, Essequibo River; ROM 101267, 3, 125.8-138.4 mm SL; ROM 101595, 1, 95.8 mm SL; ROM 101756, 6, 78.8-87.5 mm SL; ROM 101828, 1, 85.2 mm SL; ROM 101925, 4, 128.8-144.8 mm SL; ROM 101926, 2, 101.5-104.4 mm SL, Mazaruni River. Myloplus levis: Brazil: ZUFMS 4413, 1, $115.5 \mathrm{~mm}$ SL, Aquidauana, MS, Brazil; ZUFMS 4484, 2, 107.4-117.8 mm SL, Corumbá, MS, Brazil. Myloplus lobatus: Brazil: BMNH 97.11.26.8, 1, 124.2 mm SL, Rio Capim, Brazil; GEA 1988, 1, 166.7 mm SL, Rio Madeira basin. Myloplus lucienae: Brazil: INPA 30717, holotype, 130.7 mm SL, Rio Carabinani, Brazil; INPA 52894, 2 paratypes, 122.5-123.4 mm SL, Rio Negro. Myloplus planquettei: French Guyana: INPA 2260, 1, 119.5 mm SL, Maroni River; INPA 226, 1, 155.3 mm SL, La Mona River. Myloplus rhomboidalis: Brazil: GEA 1501, 1, $230.1 \mathrm{~mm}$ SL, Rio Roosevelt. Myloplus rubripinnis: Guyana: BMNH 1971.5.10.64, 1, $76.5 \mathrm{~mm}$ SL, paralectotype of Myletes rubripinnis, Essequibo River. Suriname: ZMA 105-565, 2, 168.7-190.6 mm SL, Bassin de la Saramaca; ZMA 120.251, 1, 171.6 mm SL, Lake Brokopondo. Myloplus ternetzi: French Guyana: BMNH 1926.3.2.531-532, 2 syntypes of Paramyloplus ternetzi, 157.1-163.2 mm SL, Approuague River. Myloplus tiete: Brazil: ZUFMS 2087, 1, 101 mm SL, Campo Grande, MS; ZUFMS 2902, 1, 123 mm SL, Rio Indaiá Grande, MS; ZUFMS 3703, 1, 122 mm SL, Rio Verde, PR, Brazil. Myloplus torquatus: Brazil: NMW 56449, 1 paralectotype of Myletes torquatus, $133 \mathrm{~mm}$ SL; NMW 56450, 1 lectotype of Myletes torquatus, $122 \mathrm{~mm}$ SL, Rio Branco. Myloplus zorroi: Brazil: INPA 50880, holotype, 326.2 mm SL; INPA 50868, 3 paratypes, 183.8-339.5 mm SL, Rio Aripuanã.

\section{Acknowledgments}

We are grateful to Lúcia Rapp Py-Daniel (INPA), Patrice Pruvost(MNHN), Oliver Crimmen (BMNH), Ronald de Ruiter (RMNH), Peter Bartsch (ZMB), Anja Palandacic (NMW) and Douglas Nelson (UMMZ) for support during visits to their institutions, for providing information about types, or loan of comparative material. Thanks to Kirk Winemiller (TAMU) for 
facilitating a loan of the specimens from ROM during a visit by MCA. We are especially grateful to Mary Burridge, Erling Holm, Margaret Zur and Donald Stacey (ROM) for handling the various transfers of specimens, for providing $\mathrm{x}$-ray images, and especially for over a decade of exceptional curatorial and field support to HLF. We thank Donald C. Taphorn, Devya Hemraj, Mark Ram, Kavita Dookram and Jevaun Correia for help in the field, and Priya Maharaj (CSBD) for facilitating fieldwork and obtaining collecting and export permits related to this work. Thanks to Fernando Dagosta (UFGD) for providing us valuable suggestions and recommendations to improve the original manuscript. MCA is funded by Programa Nacional de Pós-Doutorado of the Coordenação de Aperfeiçoamento de Pessoal de Nível Superior - Finance Code 001 - addressed to the Programa de Pós-Graduação em Ecologia Aquática e Pesca of UFPA (PNPD/CAPES \# 06/2017). HLF was funded by a Discovery Grant from the Natural Sciences and Engineering Research Council of Canada between 2008 and 2017, and various grants from the Royal Ontario Museum to perform fieldwork in Guyana between 2008 and 2016 . Fieldwork in the Middle Mazaruni was funded by a UGSTSP grant to study the effects of gold mining on fish communities from the University of Guiana to EAL. Fieldwork in Guyana and Suriname and support during the preparation of this paper came from startup funds from the University of Michigan to HLF.

\section{References}

Alofs KM, Liverpool EA, Taphorn DC, Bernard CR, LópezFernández H. Mind the (information) gap: The importance of exploration and discovery for assessing conservation priorities for freshwater fish. Divers Distrib. 2014; 20(1):107-13. https:// doi.org/10.1111/ddi.12127

Andrade MC, Jégu M, Gama CS. A new species of Myloplus Gill (Characiformes, Serrasalmidae) from the Tumucumaque Mountain Range, Brazil and French Guiana, with comments on M. rubripinnis. Zootaxa. 2018a; 4403(1):111-22. http://dx.doi. org/10.11646/zootaxa.4403.1.6

Andrade MC, Jégu M, Giarrizzo T. A new large species of Myloplus (Characiformes, Serrasalmidae) from the rio Madeira basin, Brazil. ZooKeys. 2016a; 571:153-67. https://doi.org/10.3897/ zookeys.571.5983

Andrade MC, Jégu M, Giarrizzo T. Tometes kranponhah and Tometes ancylorhynchus (Characiformes: Serrasalmidae), two new phytophagous serrasalmids, and the first Tometes species described from the Brazilian Shield. J Fish Biol. 2016c; 89(1):467-94. https://doi.org/10.1111/jfb.12868

Andrade MC, Jégu M, Buckup PA, Netto-Ferreira AL. A new Myleus species (Characiformes: Serrasalmidae) from the rio Tapajós basin, Brazil. J Fish Biol. 2018b; 92(6):1902-14. https://doi.org/10.1111/jfb.13628

Andrade MC, Ota RP, Bastos DA, Jégu M. Anew large Myloplus Gill 1896 from rio Negro basin, Brazilian Amazon (Characiformes: Serrasalmidae). Zootaxa. 2016b; 4205(6):571-80. http:// dx.doi.org/10.11646/zootaxa.4205.6.5
Eigenmann CH. The freshwater fishes of British Guiana, including a study of the ecological grouping of species, and the relation of the fauna of the plateau to that of the lowlands. Mem Carnegie Mus. 1912; 5(1):1-578.

Fricke R, Eschmeyer WN, Van der Laan R. Eschmeyer's catalog of fishes: genera, species, references [Internet]. San Francisco: California Academy of Science; 2019. Available from: http:// researcharchive.calacademy.org/research/ichthyology/catalog/ fishcatmain.asp

Géry J. Poissons Characoïdes des Guyanes. I. Généralités. II. Famille des Serrasalmidae. Zool Verh; 1972; 122:1-250.

Géry J. Characoids of the world. New Jersey: T.F.H. Publications; 1977.

Jardine W. Pacus of Guiana. In: Schomburgk R, Jardine W, editors. The Natural history of fishes of Guiana. Part I. Edinburgh: The Naturalists' Library; 1841. p.236-42.

Jégu M. Subfamily Serrasalminae (Pacus and Piranhas). In: Reis RE, Kullander SO, Ferraris CJ, editors. Check List of the Freshwater Fishes of South and Central America. Porto Alegre: Edipucrs; 2003. p.182-96.

Jégu M, Santos GM. Révision du statut de Myleus setiger Müller \& Troschel, 1844 et de Myleus knerii (Steindachner, 1881) (Teleostei: Characidae: Serrasalminae) avec une description complémentaire des deux espèces. Cybium. 2002; 26(1):33-57.

Jégu M, Keith P, Le Bail PY. Myloplus planquettei sp. n. (Teleostei, Characidae), une nouvelle espèce de grand Serrasalminae phytophage du bouclier guyanais. Rev Suisse Zool. 2003; 110:833-53.

Mattox GMT, Britz R, Toledo-Piza M. Skeletal development and ossification sequence of the characiform Salminus brasiliensis (Ostariophysi: Characidae). Ichthyol Explor Fres. 2014; 25:103-58.

Nico LG, Jégu M, Andrade MC. Family Serrasalmidae - Piranhas and Pacus. In: van der Sleen P, Albert JS, editors. Field guide to the fishes of the Amazon, Orinoco, and Guianas (Princeton Field Guides). Princeton: Princeton University Pres; 2018. p.172-96.

Ota RP, Rapp Py-Daniel LH, Jégu M. A new silver dollar species of Metynnis Cope, 1878 (Characiformes: Serrasalmidae) from Northwestern Brazil and Southern Venezuela. Neotrop Ichthyol. 2016; 14(4):e160023. http://dx.doi.org/10.1590/1982-022420160023

Pastana MNL, Dagosta FCP, Esguícero ALH. A new sexually dichromatic miniature Hyphessobrycon (Teleostei: Characiformes: Characidae) from the rio Formiga, upper rio Juruena basin, Mato Grosso, Brazil, with a review of sexual dichromatism in Characiformes. J Fish Biol. 2017; 91(5):130118. https://doi.org/10.1111/jfb.13449

Weitzman SH. The osteology of Brycon meeki, a generalized characid fish, with an osteological definition of the family. Stanford Ichthyol Bull. 1962; 8(1):1-77.

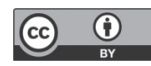

Submitted March 17, 2019 Accepted July 3, 2019 by Paulo Lucinda 